\title{
Political Financing in Africa: A Comparative Study of Kenya and Nigeria: Proposal for Reform
}

\section{Eme, Okechukwu Innocent}

\author{
Anyadike, Nkechi \\ University of Nigeria, Nsukka \\ Email: okechukwunncnt@yahoo.com \& okechukwunncnt@gmail.com
}

\section{Doi:10.5901/mjss.2014.v5n27p22}

\section{Abstract}

The linkage between money and polities is a powerful one with implications for democracy, especially in new democracies. Political finance has been identified as a source of political corruption in several countries. Political finance laws and regulations, through which political parties and candidates for office declare their funding sources, are among the main instruments. The relationships between party financing and corruption are so significant that to ignore party funding is simply to open wide the donor for corruption. Looking into Nigerian and Kenyan political history one realizes that there is much that need to be done in this regard. This is why the financing of political life is both a necessity and a problem. The frequency with which new laws concerning campaign and party finance are enacted is testimony to the failure of many existing legal frameworks and legislations. For instance, the Electoral Acts of 2002, 2006 and 2010, the Election Campaign Financing Bill 2012, the Public Collections Act 1960 review the current status of campaign and political finance regulations in Nigeria and Kenya. The cover among other issues: the regulation, management, expenditure and accountability of election campaign funds during election and referendum campaigns. This is because hardly a month goes by without a new scandal involving political money breaking out in some in this part of the globe. Political parties constitute one of the core groups of institutions in Kenya and Nigeria's democratic systems. The parties that emerged in Nigeria for instance, since Nigeria's Fourth Republic, however, are characterized by undemocratic practices and exhibited gross misconducts against transparency and accountability. At their best, political parties should nurture and articulate the expression of socio-political interest and opinion. Under current Nigerian conditions, however, most political parties lack ideologies, not issue oriented, but are merely zero-issue alliances of notables who are able to control and, often enough, manipulate party structures, candidacies and even the general electoral process itself. Most parties are vehicles in the hands of few "political entrepreneurs" who invest huge amount of money and expect concurrent rewards on such investment (in the form of public works and procurement contracts, prebendal appointments of cronies to public offices and other forms of prebendal activity). The fallout has led to mass electoral/political violence and political destabilization and disempowerment of the generality of the Nigerian electors, the exclusion of alternative parties seeking to participate in electoral politics and the absence of an effective system to regulate political finance. This paper seeks to explore the concept of political finance. It will equally attempt to concisely analyze the extant legal framework regulating political finance in Kenya and Nigeria, highlight their inadequacies with a view of reforming these inadequacies for a better political finance management and best practices and proffer suggestions on the ways forward drawing freely from the instructive practices of other emerging and advanced democracies.

Keywords: Political finance, Political party, Reform, Prebendalism, Election, Electoral laws and Legislations.

\section{Introduction}

Campaign financing has been a major concern in Kenya and Nigeria. Significant and unregulated campaign financing often create an uneven playing field in election contest. Large sums of money give certain parties and/or candidates undue advantage over others. Very often the candidates with the most money always win the election or party nomination process. Wide discrepancies in levels of funding between parties and candidates constrains opportunities for political competition and tend to disenfranchise challengers.

Most often, the uneven playing field results from the fact that the ruling party or the incumbent candidate control political apparatus and uses it to its own advantage and to the disadvantages of challengers. The financial requirements for entry to electoral competition appear to be getting higher and higher, resulting in political exclusion of those who cannot afford the cost. Another concern has been that elected officials are becoming more accountable to those who finance their campaigns than to their constituents. Large corporate or single donor funding for parties and candidates dominates political decisions and political corruption is a national problem, posing a threat to the Nigerian and Kenyan 
economic growth, democracy, and the stability of the countries. Nearly all major financial and corruption scandals in recent times have been linked to campaign and political financing.

The 2013 election season in Kenya just like in Nigeria in 2011 will be remembered as the most expensive in history as it came with more elective posts on the ballot papers and candidates investing much more to win voters to their side. The money spent during the campaigns did not only stay at the top, but has also trickled down to local traders who got the chance to sell their wares to thousands whenever the candidates held big rallies. The bulk of the money went into travel, operations, events, media adverts and merchandise. From helicopters to fixed wing aeroplanes, hundreds of branded vehicles, campaign materials and media campaigns, presidential candidates and their parties have gone all out. According to businessdailyafrica.com (2013), it is estimated that the four main coalitions - Amani, Cord, Eagle and Jubilee - are spending as much as Sh10 million $(\$ 115,000)$ every day to hire helicopters for their campaigns, according to figures obtained from players in the aviation industry. Jubilee Alliance, led by Uhuru Kenyatta and his running mate William Ruto, has six helicopters and four fixed wing aeroplanes on its campaign trail. The Raila Odinga-led Cord Coalition has four helicopters and two fixed wing aeroplanes. The Musalia Mudavadi-led Amani Coalition also has five helicopters and one fixed-wing aircraft, while the Eagle Coalition, whose presidential candidate is Peter Kenneth, has one helicopter. The cost of hiring a chopper ranges from $\$ 1,500($ Sh130,500) to $\$ 2,000($ Sh174,000) per hour, depending on the organisation. ALS Limited, based at Wilson Airport with a fleet of 23 both fixed wing aircraft and helicopters, charges about $\$ 1,700$ (Sh147,900) per hour for its helicopters, with the minimum time one can pay for being two hours.

In Nigeria today, sponsorship of a political party or candidate is effectively a business investment, which the investor must recoup the moment his candidate gets into public office. The very peculiar nature of Nigeria's socioeconomic environment characterized by hunger and literacy make the electors and indeed government agencies susceptible to manipulation by corrupt politicians who take advantage of inadequate electoral laws which creates a leeway to unlimited access to political finance sufficient to destroy the electoral process.

How political parties finance their campaigns is critical in any democratic election. Researchers at the University of Ibadan, Nigeria and the Centre for the Study of African Economies (CSAE), University of Oxford, U.K. investigated how political parties in Nigeria finance their campaigns. The most important question was to what extent campaign finance determines electoral victory. The key results are:

Candidates invest large amounts of their private savings to contend in the elections. This means that only individuals willing to invest large amounts of money become candidates. Money distorts the candidate selection process within parties and largely influences who wins the elections. Electoral laws governing how parties should secure and spend their funds are ineffective as there is a lack of knowledge about them. As a result such laws have limited enforceability Okunade et al (2009)

The broad commitment of the administration of Chief Olusegun Obasanjo to governance reform as highlighted by Okunade et al (2009) and evident in the enactment of anti-graft laws and policies, is indicative of new policy consciousness and official perception of the problem of corruption. The Obasanjo administration set up a High-powered Technical Committee to review the restructuring of governance at the local government level. The Committee was to, among other things; examine the problem of inefficiency and high cost of governance in the country, with a view to reducing costs and wastes at the three tiers of government. The committee was required to examine the high cost of Election Campaigns in the country and consider, among other options, the desirability of Political Parties, rather than individual office seekers, canvassing for votes in elections. Again, former President Obasanjo, in an address at the INECCivil Society Forum Seminar on 27th November 2003, lamented at the dangers associated with uncontrolled use of money during elections: His words:

With so much resources being deployed to capture elective offices, it is not difficult to see the correlation between politics and the potential for high level corruption. The greatest losers are the ordinary people, those voters whose faith and investment in the system are hijacked and subverted because money, not their will, is made the determining factor in elections. Can we not move from politics of money and materialism to politics of ideas, issues and development? (Guobadia, 2005:5).

He went on at the same forum to examine the cost of conducting elections in Nigeria. He explained thus:

Even more worrisome, however, is the total absence of any controls on spending by candidates and parties towards elections. I have said that we prepare for elections as if we are going to war, and I can state without hesitation, drawing from my previous life, that the parties and candidates together spent during the last elections, more than would have been needed to fight a successful war. The will of the people cannot find expression and flourish in the face of so much money directed solely at achieving victory. Elective offices become mere commodities to be purchased by the highest bidder, and those who literally invest merely see it as an avenue to recoup and make profits. Politics becomes business, and the business of politics becomes merely to divert public funds from the crying needs of our people for real 
development in their lives (Guobadia, 2005:6).

The legislation on campaign financing must provide effective regulatory regime for addressing these problems. The Centre for Multi-party Democracy Kenya (CMD-Kenya), ARTICLE 19, Electoral Reform Network and Organized Civil Society in Nigeria are consistent in their support for reforms that strengthen multi-party democracy. We share the view that democracy requires strong party organizations that compete for political power in fair elections and to keep the system functioning, political parties and individual candidates must have the resources to run successful campaigns.

From the thesis, the relationship between money and politics is a powerful one with implications for democracy, especially in new democracies. Political party finance has been identified as a source of corruption in several countries. Political finance laws and regulation, through which political parties and candidates for political office declare their funding sources, are among the main instruments. Recent history has witnessed the pooling together of resources all over the world into a network of global awareness against unregulated use of money in politics. This paper is part of the debate and will attempt to concisely examine different types of political party financing in Nigeria and Kenya, highlight inadequacies that are inherent and proffer suggestions on the way forward.

\section{Political Finance}

The term "Political Finance" has been defined by Ujo (2000), Walecki (2002); Ilo (2004) Obiorah (2004), Pinto-Duschinsky (2001 and 2004), Emelonye (2004), Kukah (2006) and (Ayoade) as the use of money or the use of other material resources for political activities. It also embodies the sources or means through which political activities are sponsored in a given polity. The concept of political finance has two broad connotation viz money used for electioneering (campaign funds) and money used for political party expenses (party funds). Though there are other forms of political finance but these two will form the basis of our discussion because they constitute the foundation of every political activity.

This broad definition of political finance while capturing the essence of the term does not acknowledge the multiplicity of forms and ways in which the monetization of politics may be used to influence political outcomes. The definition offered by Pinto - Duschinky (2001) also fails to capture the centrality of "political". That is, it shies away from explicating the ambits of the term "political". According to Emelonye (2004:34), what the present author advocates here is not a semantic description but rather a clarification as to construction of the term when it comes to foreign contributions. For example, in issued, the definition of "political" is narrowed soon that foreign payments for technical assistance" and training are permitted. But such terms may be guises for more partisan contributions with political undertones or motives such as support for private governments' business forms and convert propaganda).

Pinto-Duschinsky (2004) modified his earlier thesis by positing that political finance is "money for electioneering". Since political parties play a critical part in election campaigns in many parts of the globe, and since it is difficult to draw a distinct line between campaign costs of party organizations and their routine expenses, party funds may reasonably be considered "political finance", too. He goes on to argue that party funding includes not only campaign expenses but also the costs of maintaining permanent offices, carrying out policy research, and engaging in political education, voters registration, and other regular functions of parties.

Therefore, a definition of political finance should include the underlisted aspects which Pinto-Duschinsky (2004) subsequently identified in his contribution:

1. That political finance is a feature of non-democratic, as well as democratic regimes

2. The expenditure on elections and parties is only a part of a more far reaching issue. Political funding can be for activities ranging from lobbying, propaganda, support of interest groups to blatant bribery and

3. That the regulation of political finance is hindered by a plurality of avenues of obtaining and using money for political ends.

The Electoral Acts (2002, 2006 and 2010) contain numerous provisions in relation to political party and election finance. The Electoral Act (2002) defines election expenses in section 84 (1) as follows: "expenses incurred by a political party within the period from the date notice is given by the commission to conduct election up to and including the polling day in respect of the particular election.

This definition is flawed totality because experience has shown that in Nigeria most election expenses are incurred by the candidates themselves and not the political parties. This definition is restrictive automatically excludes the election expenses incurred by candidates from whatever limitations on election expenses.

The Electoral Act (2006) has introduced ceilings on contributions by individuals to political parties and on the campaign expenses by political parties and candidates alike. Section 93 stipulates that election expenses by every candidate shall not exceed:

1. N500 million for presidential candidates 
2. N 100 million for Governorship

3. N 20 million for Senate

4. N 10 million for House of representatives

5. N 5 million for State Assembly

6. $\quad$ N 5 million for Chairmanship of Local Government council and

7. N 500, 000 for Councillorship.

In addition, no individual shall donate more than N1 million to any candidate. Notation of this provision attracts fines raging from $\mathrm{N} 100,000$ or 1 month imprisonment or both for councillorship candidates, to N1 million or 12 months imprisonment or both for presidential candidates, while any individual who do notes more than N1 million to any candidate is liable to a fine of $\mathrm{N500,000}$ or 9 months imprisonment or both. The electoral commission is left to fix the maximum donation any person can make to a political party (section 92) as apposed to a candidate who is stipulated in section 93. No party can accept or keep anonymous contributions of more than $\mathrm{N} 100,000$ unless it can identify the source of the money and must keep records of all donations over N1 million.

The underlisted puzzles come up for the Independent National Electoral Commission for consideration:

1. Has INEC undertaken an examination and audit of the accounts of the political parties?

2. Did the Commission place any limit on the amount of contribution which individuals or cooperate agencies made to political parties in the course of fund raising for the 2003, 2007 and 2011 elections?

3. Do all political parties have records of all contributions to their campaign funds?

4. does INEC have a record, which shows the total expenses of all the political parties for the purposes of invoking the provisions of section 84, 92 and 93 sub sections (2), (3) and (6) of the 2004, 2006 and 2010 Electoral Acts?

5. What steps have been taken to sanction corporate bodies that contributed to the campaign funds of political parties in total disregard of the provisions of section 38 (2) of the company and Allied matters Act (1990), which prohibits donations or gifts of any of its property or funds to a political party or association.

At present, only INEC can attempt the above questions. For the purpose of this paper the term "political finance" refers to the deployment of financial and material resources by both political parties and politicians as prescribed by law of the polity to cover political expenses.

The Draft Campaign Financing Bill, 2011 ("the Draft Bill") of Kenya, which is currently undergoing a stakeholder review process by the Constitutional Implementation Committee of Kenya is a welcome initiative that will foster greater transparency and accountability in the financing of election and referendum campaigns. However, a number of shortcomings in the Draft Bill like those of Nigeria jeopardise these objectives, and a series of amendments are required before the Draft Bill complies with international standards on freedom of expression and information. The Campaign Financing Bill, 2011 sets out major reforms for funding of election campaigns, use of campaign funds in the nomination process, election campaign and elections. It will provide for the management, spending and accountability of funds during election and referendum campaign.

It is important that the draft bill is clear on the concept of campaign financing to prevent any political and administrative frustration and even litigation in Court. CMD-Kenya believes that campaign financing refers to the manner in which political parties and individual candidates who seek to get elected to political office gather, utilize, and recover funds for electoral campaigns and in the case of political parties seek to maintain themselves as organisations. In this context the scope of the legislation should cover all aspects of campaign financing. We believe that the conceptual framework needs to be reflected in the interpretation to give the legislation effective statutory interpretation (CMD-Kenya, 2011).

In the analysis, ARTICLE 19 (2012) emphasises that transparency in campaign financing is indispensable for embedding accountability and integral to the promotion of good governance and democracy. Only with full access to information can the media scrutinise the conduct of election candidates and inform public debate on the dynamics and distribution of political and economic power in Kenya. The engagement that transparency fosters between candidates for public office and the electorate also maximises enjoyment of the right to political participation. The analysis finds that positive measures in the Draft Bill include the establishment of limits on political campaign expenditures, caps on the amount individuals can donate to candidates, and the imposition of a ban on anonymous donations. The establishment of a framework for the collection and reporting of data to a new Oversight Committee is a significant step towards furthering a culture of accountability in the financing of political campaigns.

However, ARTICLE 19 (2012) also finds that various elements of the Draft Bill fall short of international standards on freedom of expression and access to information. The Draft Bill designates as confidential all campaign financing information submitted to the oversight Committee, with only limited disclosure exceptions for information that is the 
subject of a complaint or investigation. This runs counter to the principles of proactive and maximum disclosure that are central to the right of access to information. The selection criteria for the Oversight Committee are also left ambiguous, and there are inadequate safeguards to ensure the accountability of this committee to the public.

In conclusion, ARTICLE 19 (2012) urges the Kenyan legislature to revise the Draft Bill and adopt it only after it is brought into compliance with international standards on freedom of expression and information. The need for greater transparency in all aspects of public life in Kenya further demonstrates the urgent need for a comprehensive access to information framework to be implemented in the country.

\section{The Sources and Legal Framework for Funding of Political Parties in Nigeria: Lessons for Kenya}

The sources of funding political parties in Nigeria between the Second, Third and the Fourth Republics were:

1. Statutory allocation

2. Fees and subscription and

3. Lawful donations and public collection respectively.

A number of constitutional provisional provisions and legislative enactments relate to political finance. The Constitution of Nigeria provides the basic framework for the implementation and enactment of other laws in the polity. The supremacy of the constitution is further emphasized in section 1 (3), which provides "if any other law is inconsistent with the provisions of this constitution, this constitution shall prevail, and that other law shall to the extent of the inconsistency be void" (The Constitution, 1999:1).

In other words, every other law in the country must be in line with the provisions of the constitution. It also follows that any inadequacy in the constitution will automatically taint the provisions of subsequent laws in the same subject matter. The 1999 constitution in section 221 prohibits any association other than political parties from making political donations. The constitution in section 225 provides as follows:

(1) Every political party shall, at such times and in such manner as the Independent National Electoral Commission may require, submit to the Independent National Electoral Commission a statement of its assets and liabilities.

(2) Every political party shall submit to the Independent National Electoral Commission a detailed annual statement and analysis of its sources of funds and other assets together with similar statements of its expenditure in such form as the Commission may require.

(3) No political party shall - (a) hold or posses any funds or other assets outside Nigeria; or (b) be entitled to retain any funds or other assets outside Nigeria

(4) Any funds or other assets remitted or sent to a political party from outside Nigeria shall be paid over or transferred to the Commission within twenty-one days of its receipt with such information as the Commission may require.

(5) The Commission shall have power to give directions to political parties regarding the books or records of financial transactions which they shall keep and, to examine the all such books and rerecords.

The Commission was also empowered in subsection 6 of the above section to audit the account of political parties through its staff or professional auditors. The commission is further empowered by section 226 of the constitution to prepare and submit a report on the financial account of the political parties to the National Assembly and are authorized to have unlimited assess to the records of the political parties. The National Assembly is empowered in section 228 of the 1999 constitution to make laws for the punishment of any individual or party who fails foul of the above provisions and the disbursement of annual grants to political parties.

\section{The Electoral Act 2002}

The provision of this law covers virtually every process of electoral activities in the country. Section 76 provides for the oversight function of the Electoral Commission over the activities of the political parties and also provides for a fine of N500, 000 for non-conformity by any individual to lawful directions by the Commission in carrying out its supervisory functions.

Section 77 makes provision for a fine of N500, 000 for the contravention of section 225 (3) (a) and (b) of the 1999 Constitution relating to ownership of foreign asset by any political party and any donation from outside the country.

Section 78 provides for period of time, which the annual account of a political party should cover. It also empowered the Commission to audit the account of political parties periodically. Section 79 makes provision for a separate finance statement for election expenses as prescribed in section 100 of the act not latter than 90 days after the 
election. Surprisingly section 100 of the Electoral Act has no provision whatsoever that relates to party finances it rather talks about qualification of a person who can contest elections.

Any political party that fails to submit the audited return of election expenses is guilty of an offense punishable on conviction with a fine of $\mathrm{N100,000}$. Section 80 makes provision for the disbursement of grants to political parties that are contesting elections. It provides that $30 \%$ of the grant shall be distributed equally among the political parties before the election and the remaining $70 \%$ shall be shared among the political parties after the result of the election has been known, in proportion to the number of seats won by each party in the National Assembly.

Section 81 provides that the National Assembly may make an annual grant to political parties and $30 \%$ of such grants should be shared among the political parties in proportion to number of seats won by each party in the National Assembly.

Section 82 provides as follows:

No political party shall be eligible to receive a grant under section 93 unless it wins a minimum of 10 percent of the total votes cast in the local government election in at least two-thirds of the states of the federation. Section 93 which is referred to in the above provision has no such provisions. Section 83 empowers the Commission to place the limitation on the amount of money or other assets, which an individual or corporate body can contribute to a political party. Also it stipulates for a record of all contributions.

\section{Electoral Act 2006}

Under the 2006 Electoral Act which was used in the conduct of the 2007 elections while the recommendations of the Uwais Panel was being debated, the National Assembly was empowered to approve a grant to be disbursed to political parties. The 2006 law also stipulates how the grant should be divided, 10 percent going to be shared equally among the registered political parties and the remaining 90 percent disbursed in proportion to the number of National Assembly seats won by each party. The law also gives INEC the power to place a limit on the amount of money or other assets an individual or group can contribute to a political party. For a presidential candidate the sum is N500 million, governor N100 million, senator N20 million and a representative N10 million. A state assembly candidate, or chairman N5 million and a local councillorship, N500,000.

It is an open question whether this aspect of the electoral law has ever been paid attention to not to talk of being enforced. Some of the then 50 parties have not in any way justified the money they receive from government. It has been discovered that some of the parties only exist on the pages of newspapers and magazines. They only function when elections are coming or when funding is released by government. They collect the funds, share and go home to rest till another round of funding is available. A few of the parties are even run by close-knit family members. So what does a party exist for if it is only to share government funds?

As the nation moved towards 2011 elections, it became imperative to revisit the issue of political financing in Nigeria. The Uwais Panel report recommended the continued funding of parties by government through INEC, but suggests a ceiling for individual donations for each category of office. These figures run from a limit of N20 million for individual donations for a presidential candidate to N15 million for a governor, N10 million for a senator, N3 million for a local government chairmanship candidate. It makes eminent sense for party members to fund their own organization. The Uwais panel recommends that only parties that score 2.5 percent of the votes in the 2011 elections should be eligible to receive funds from public grants, but this like many other issues where expunged in the 2010 Electoral Act.

\section{Electoral Act 2010}

The 2011 General Elections are over with local and international acclamation to the electoral commission. The elections were not flawless; however, Nigerians and foreign witnesses are unanimous that the just concluded polls were held in substantial compliance with the nation's electoral laws. It is too early to pre-empt the political parties on the veracity of the election expenses they will submit to INEC in the next 6 months. But then, is six months not too long? I should think three months after the polls is okay, more so as candidates, who spend the bulk of the campaign money, are not yet under obligation to submit election expenses report.

This post election period, two major things must happen. The first is for the Independent National Electoral Commission (INEC) to rise up to its constitutional duty to enforce political finance provisions as contained in the statutes viz. the 1999 Constitution (as amended), the Electoral Act 2010 (as amended) as well as the Political Party Finance Manual and Handbook. The second matter of urgent national importance is the amendment of these laws to make them more enforceable. The current legal framework requested three reports from the political parties. The first, according to 
section 89 of the Electoral Act 2010, is the annual statement of assets and liabilities, analysis of their sources of funds and other assets as well as their statements of expenditure. INEC is mandated to publish the report in three national newspapers.

The other report which is of greater interest to campaign finance experts is stated in section 92 of the current electoral act. Sub-section 3 of the clause says "Election expenses of a political party shall be submitted to the Commission in a separate audited return within 6 months after an election and such return shall be signed by the party's auditors and counter signed by the chairman of the party and be supported by a sworn affidavit by the signatories as to the correctness of its contents". Sub-section 5 states that the return shall show the amount of money expended by or on behalf of the party on election expenses, the items of expenditure and the commercial value of goods and services received for election purpose. Sub section 6 mandated the political parties to publish this report in at least two national newspapers. The third report is requested of political parties in section 93 (4) and it states that "A political party sponsoring the election of a candidate shall within 3 months after the announcement of the results of the election, file a report of the contributions made by individuals and entities to the Commission". Hitherto, these provisions have been violated with impunity. If the truth will be told, the last general election in Nigeria was the most expensive in the annals of our electoral democracy. Given the resources deployed by some of the wealthy candidates during the elections, there is no gainsaying the fact that the contestants showed scant regards for the provision of section 91 subsections $2-5$ of the Electoral Act 2010 which placed a cap on the amount of money they are to spend on their campaigns.

\section{Other Legal Frameworks}

The Companies and Allied Matters Act forbids corporate organizations from making political donations. The abovementioned provisions if properly applied will inject some semblance of sanity in our political environment but that does not mean that there are no rooms for improvement. Section 226 provides that the Commission shall prepare and submit the annual report on the accounts and balance sheet of every political party to the National Assembly. The National Assembly is made up of partisan members who may not be free from bias in considering the reports. An independent body made up of non-partisan members should be in a better position to review such reports. The peculiar inclination of our politicians to place selfish and party interest above common good must not be overlooked.

It is submitted that the penalty provided in section 76, 77 and 78 of the 2002 Electoral Act are not stiff enough to deter parties from flouting the provisions of the law. Mere imposition of fine without more cannot adequately serve as an effective deterrent. The law should be tightened to disqualify such a party from taking part in the general elections. Our environment is one riddled by corruption and fraud. Nigerians are notorious for trivializing the provisions of the law; it then becomes necessary that in other to save our democracy very stiff penalties must be prescribed for serious offenses. The penalties as applied presently have not been able to check the excesses of political parties and politicians.

The provision of section 80 of the Electoral Act which stipulates that the grant given to political parties should be shared before and after elections and on the latter instance in proportion to the seats the political parties have in the National Assembly destroys the sole aim of the grant which is to help the political parties especially the small ones contest election. Sharing $70 \%$ of the grant after election to successful parties empowers the bigger parties the more and does not promote fair and level plying ground. This argument also applies to the provisions of sections 81 and 82 of the Electoral Act.

The reference made to wrong provisions in section 79 and 82 portrays the carelessness and inefficiency of the draftsmen and the legislators who passed it into law. The Act in section 83 contradicts the provisions of section 308 of the Companies and Allied Matters Act, which prohibits corporate bodies from making political donations. This provision of the Act amplifies the very careless attitude of the draftsmen and creates confusion in the political environment. Allowing corporate bodies to make political donation will open up ways for the sale of the seat of government. It creates room for money politics as seen in the last election. Till date INEC has not placed any limitation on the amount of money an individual or corporation can donate to political parties allowing room for money bags to hijack the political parties and even the government as seen in the drama which unfolded in Anambra, Ogun, Oyo and Imo States respectively.

To monitor expenses of candidates the Draft Bill (Political Finance Bill 2004) presented by INEC to National Assembly required every candidate to file a return under oath of his/her election expenses within 2 months after the result of the election, after which the commission is required to publish some within 10 days of receipt. Again for reasons which we are not privy to, the law makers refused to publish such statements (which fortunately is a constitutional requirement under section 225 and 226 of the 1999 constitution).

Government may fund political parties in an indirect way. Indirect public funding includes:

1. free broad casting time 
2. State payment in the legislature

3. Use of government facilities and personnel

4. State grants to party foundations

5. Tax relief, tax credits and matching grants (Pinto-Duschinsky, 2002 and Ujo, 2000:25).

Membership subscription is another source of political party funding. The size of such funds depends on the membership strength of the party. As observed by Ujo (2000:126) while quoting Pinto-Duschinsky (1998).

In most countries, membership levels have been falling. Income subscription is rarely a major constituent of our party income. A recent comparative study of political financing in European countries concluded that membership subscription play "only a limited role" in present day party finances. Other sources of funding political parties include:

Institutions

1. Business Corporations

2. Trade Unions

3. Fund Raising Activities

4. In-kind Contributions

5. profit from party-owned business activities

6. foreign contribution

7. Interest groups (Ujo, 2000:126).

The fundamental objectives of regulating political financing as cited by Cross (2004:1430) includes:

1. Probity and transparency in order to preserve voters confidence that system is free from corruption and quid pro quo arrangements

2. equity to ensure a balanced playing field among parties and candidates, with name vastly outspending the others

3. Accessibility to electoral competition for all citizens regardless of their financial status.

Irrespective of the good intensions of the government, the above objectives are unattainable as a result of "corrupt" political financing. According to Pinto-Duschinsky (2001 and 2004), "corrupt" political financing usually refers to one of the following:

1. Political contributions that contravene existing laws on political financing

2. The use for campaign or party objectives of money that a political office holder has received from a corrupt transaction.

3. Unauthorized use of state resources for partisan political purposes.

4. Acceptance of money in return for an authorized favour or the promise of a favour in the event of election to an office.

5. Contributions from disrespectable sources and

6. Spending of money on banned purposes such as vote-buying (Pinto-Duschinsky, 2004:6-16).

A discussion of political party finance has to grapple with the origins of the money and accounting for their usage. That is what is the source of the funds and how are they used. Universally, corruption, bribery, vote buying and election related financial malpractices have necessitated calls for electoral reforms to address the anomalies. Generally there are three different sources of money that parties accrue their finances from. These are first, internal finances such as members' dues and membership fees, second private donations, and third state/public funding. The latter are the subsidies provided by the state to parties, candidates for campaigns in the form of direct payments, campaign reimbursements, and in other cases free media time. However public funding has its inherent dangers, which include over dependence on the state for funding which may hinder the independence of political parties; capitalization that primarily leads to concerns on the possibility of exchange of large donations for political favours. Commercialization that is, the increased use of political consultants that leads to political parties' decreased consultation as well as less reliance on members.

These problems inevitably lead to alienation of parties from their members and vice versa. But in spite of these shortfalls state financing has largely been supported on grounds that, since parties and electoral competition are essential for democracy, it is only fair that the state provides them some support. In addition, with the ever-increasing costs of elections, there may not be enough private financing for all parties. Therefore public funds are the only way to ensure equality. Skeptics have however faulted public funding on grounds that, funding may lead to state interference in the internal affairs of the parties or lead to ossification of the party system. In other words, the party system will not change and encourage new competition because parties that might have otherwise faded away continue to exist as a result of state funding. In addition parties will become less dependent on members dues, thus becoming coteries of the state, rather than articulating the interest of the people. As Von Beyme argues "public funding is a proof that parties have 
lost their social critical function and are ossifying in the arms of the state." In order to address these anomalies legislation should be designed legislation should be designed in a way that ensures that fundraising does not become the main preoccupation of parties. Likewise, funding should be designed to grant parties a degree of autonomy from private interest. To this end, legislation on contribution limits for instance can be enacted to ensure that one individual or group does not have a disproportional influence on parties, elections or the policy decisions of representatives. By limiting the number of big donors to each party it limits the possibility of one party having a large advantage over others. It can also be argued that contribution limits can enhance the autonomy of parties and lessen the commercialization of politics since parties would no longer rely on large contributors, which in turn would make them less susceptible to influence to contributors of large donations. This argument is however oblivious of the fact that these limits might actually increase the time spent on fundraising since the number of donors required to maintain current income levels would increase since instead of a few large donors many small donors would be needed. Specifically, the next part of the paper will address these problems in detail.

\section{The Problems with Political Finance in Nigeria \& Kenya}

Money, according to llo (2004:23) is very fundamental to the activities of any political party. Insufficient finances will cripple a political party and make them insignificant. On the other hand unlimited access to finance tends to give a party an unjust edge over other parties and turns the whole process into an auction where the highest bidder wins. Though it is not all case that the richer political party wins but the truth is that it creates an unhealthy playing ground and has a tendency of corrupting the process and the government. The middle line is the political system where the political parties are equipped to reasonably contest and win election, and in which money is just one of the tools and not the only means for electoral victory.

The Nigerian environment is saddled with the two extreme positions. While some parties can barely pay for their secretariat, others have unlimited access to funds capable of enabling them corrupt the electoral process. Many reasons have been adduced to account for this situation, chiefly amongst which is that our electoral laws are not adequate to check the excuses of the politicians. Accepted that there is room for improvement in our electoral laws, it is only a part of the problem. The greatest problem with political finance in Nigeria is that the laws in force are not implemented. The Independent National Electoral Commission in the last elections never implemented the laws relating to disclosure.

In Kenya, ARTICLE 19's (2011) analysis builds upon the extensive work that ARTICLE 19 has done to promote and protect the right to freedom of expression and information in Kenya. In recent years, Kenya and East Africa, as part of the Freedom of Information Network in Kenya, has tirelessly advocated for the adoption of a dedicated freedom of information law in the country. In furtherance of these efforts they have reviewed numerous drafts of Freedom of Information legislation, supporting the process for implementing the right as guaranteed in Article 35 of the Kenya Constitution. They have also produced analyses of legislation such as the Media Council of Kenya Bill 2006, the Communications (Broadcasting) Regulations 2009 and 2011 and the harmonized Draft Constitution. Additionally, ARTICLE 19 has analysed numerous election-related laws in various countries for their compliance with freedom of expression standards, lending our expertise to legal reform initiatives worldwide. They have also produced three standard-setting documents relevant to the use of media during elections, in particular, the Guidelines for Election Broadcasting in Transitional Democracies, and Reporting Elections Broadcast Guidelines.

Recently, ARTICLE 19 have also analysed the Kenyan Publication of Electoral Opinion Bill, 2011. The analysis of the Draft Bill emphasises that transparency in campaign financing is indispensable for embedding accountability and integral to the promotion of good governance and democracy. Only with full access to information can the media scrutinise the conduct of election candidates and inform public debate on the dynamics and distribution of political and economic power in Kenya. The engagement that transparency fosters between candidates for public office and the electorate also maximises enjoyment of the right to political participation.

\section{Agenda for Reform}

The impact of money on politics is unquestionable. The availability or otherwise of money has enormous influence on the conduct and nature of general elections in all democracies whether consolidated or transitional. It is now common knowledge those elections have become very costly not only to the governments that have to manage them, but also to the political parties and individual candidates. The high costs of elections have direct bearing on two ingredients of electoral democracy, namely, popular participation and fair contestation. Indeed, it has been argued that the large sums of money spent in elections have had tragic effects on democracy including deterring citizens from political participation. 
There is also the danger that as elections become more expensive and campaign spending increases considerably, effective participation will be absent from the election campaigns. This is likely to lead to the poor losing confidence in the efficacy of their contribution to the democratic process. Another effect is that when elections become expensive, fund raising becomes the pre-occupation of politicians thereby distracting them from public policy making and their role as trustees of public interest.

The role of money in politics is a major concern, for any nation that adheres to democratic tenets. This raises concern because wealth creates unequal opportunity for participation. The source of funding itself is also a vexing issue, given that corporate funding of the political process generally increases non-participation in self-governance; it can be said to have the perverse effect of minimizing democracy and promoting the inevitable elite plutocracy. However although it is evident that the cost of elections is high there is lack of comprehensive data showing, on the one hand, what the political parties and their candidates spent in any given election, and on the other hand, what state organs responsible for the management of elections spend. Parties are reluctant to expose their expenditure data, whether this is for presidential, parliamentary or sub-territorial elections. Since the process of electioneering is a multi-activity undertaking by political parties, it requires heavy financing which in turn influences electoral competitions and outcomes. However, if only certain groups donate and only a select few receive money, then the electoral market place becomes limited to only those with means to gain entry. In addition, the buying of votes as well as unethical receipt and expenditure of funds, can have a corruption influence in the governing process. The end result is that under such circumstances money can lead to negative consequences such as decreased competitiveness and corruption.

The funding debate emerged in 2011 when reports claimed that President Goodluck Jonathan's campaign chiefs plan to deliver a landslide victory in the April polls through a war chest of N2.9 billion purportedly set aside to capture just the Southwest. The President had, however, denied, noting that he received the report with regret and sadness. His then spokesman, Ima Niboro, in a statement in Abuja, urged opposition parties to consider the unity and progress of the country and admonished them on the need to avoid doing irreparable damage to hallowed national institutions through falsehood and political skullduggery. Parts of the statement read:

The entire report has no factual basis and its contents are product of the mischief-driven imagination of its authors. President Jonathan who has been busy touring all the states of the federation, including the Southwest, in an all-out effort to win the hearts and minds of Nigerians in the traditional and politically-correct manner, has absolutely no need to resort to any underhand tactics to win the presidential elections. The President and his supporters across the country are working extremely hard to achieve success in the elections in an indisputable and transparent manner (Obo, 2011:1).

Hopes of politicians having easy access to public funds through grants to political parties from Independent National Electoral Commission (INEC) were dashed as the Senate had late last year eliminated grants from the Electoral Act. Section 89 of 2006 Electoral Act which stipulated that 10 percent of total grants to political parties are to be shared by political parties contesting elections while Section 90 stipulates that National Assembly would determine the grants to the political parties.

Most Nigerian political parties lack accountability and transparency in their fiscal practices, a report on the finances of the parties by the Independent National Electoral Commission (INEC) has shown. For at least three consecutive years, the Commission has prepared damning reports on the state of finances of the existing political parties in the country. Most of the parties are always found wanting. But in all those years, neither INEC nor the National Assembly, to which the reports are sent, has made a move to sanction the errant parties.

The latest external auditors reports on the accounts of the political parties for 2008, obtained by NEXTnewspaper, indicates that only 14 of the 54 political parties recognized by INEC at the time had adequate financial records.

Some parties, including the People's Democratic Party, have consistently flouted the Electoral Act. Other major parties; the PDP, the Action Congress of Nigeria (ACN), the Labour Party (LP), the Progressive Peoples Alliance (PPA) all had questionable records.

Out of the major political parties, only the All Nigeria People's Party (ANPP) had its financial papers in order.

Nigeria's largest party, the PDP, which also has majority representation at the local, state, and federal government levels, could not account for the finances it received in 2008; neither did it conduct any internal audits that year.

"The party does not maintain a Donation Register which is contrary to Section 95(2a) of the Electoral Act 2000," (NEXT Editorial, 2011) INEC's external auditors reported.

The Constitution and the Electoral Act, confer an oversight responsibility on INEC and the National Assembly 'to monitor the organization and operation of the Political Parties, including their finances'. Specifically, INEC is mandated to arrange for 'the annual examination and audit of the funds and accounts of political parties', according to Section 15(d) of the Constitution.

Section 226(1) of the Constitution makes it mandatory for the National Assembly to obtain the annual account of all 
political parties. Mr. Ojo who spoke to NEXT newspaper argued that the Senate ought to take the blame if the audit reports have not been acted upon and if the erring parties have not been sanctioned.

But responding to Mr. Ojo's allegations through its Committee Chairman on Information, Senator Ayogu Eze who posited that the Senate is not sure whether or not the records for 2006, 2007, and 2008 were submitted to the National Assembly. Ayogu Eze, the spokesperson for the Senate said could not say if he had received any political parties audit reports from INEC in the past four years. Similarly, The Senate Committee on INEC could explain why the Senate has not acted on the audit reports.

In an effort towards correcting inactions of those institutions and agencies trusted with the responsibilities of unregulated political finances, global public opinions have come to ginger them into action. The critical forces in this consciousness mobilization include mass mobilization on global scale, capacity building for civil society organizations and support for electoral reform programs by bilateral and multilateral donors and development partners. All around the world there is increasing pressure for the regulation of private funding to political parties. In the US, the McCain-Feingold Bill was passed and in UK the Political Parties, Elections and Referendums Act was passed in 1997 after a series of allegations of corruption.

In South Africa the demand for regulation is growing. At African regional level the AU Convention on Combating and Preventing Corruption includes a clause on the importance of regulating private funding and calls states to do so. As Nigeria derives more strength from the global current and the new policy consciousness against corruption is institutionalized via the creation of agencies and commissions, more attention need to be paid to how to regulate political party funding. The links between party financing and corruption are so important that to ignore party financing is simply to open wide the door for corruption. Looking into Nigerian political history one realizes that there is much that need to be done in this regard.

Political financing and campaign regulation have been an important electoral reform issue since the last decade in Nigeria. They have been the subjects of much debate and examinations. The central thesis has been driven largely by a growing concern over the cost of election campaigns, campaign spending by political parties and candidates, and the fund raising activities of political parties and candidates. Underlying the push for reform has also been a desire to introduce some degrees of financial fairness among candidates and parties. In order to achieve this, the underlisted recommendations are suggested:

1. The composition and independence of the electoral body in Nigeria (INEC) needs to be reorganized. For example, the powers of the President to appoint chairman, commissioners and members need to be amended to provide for or allow the organized civil society and political parties to be part of the selection process to provide for a more objective and concentrative process. INEC funding should continue to remain independent of the Chief executive interference as Uwais Panel recommended and sustained by the presidency.

2. The shortcomings of the present Electoral Act (2010) with respect to campaign financing could be addressed by either a comprehensive amendment or the enactment of separate legislation on the issue.

3. Campaign finance legislation should regulate the funding of parties, ban use of state resources for political, personal or campaign purposes and regulate and strictly enforce the clauses/provisions of free airtime and media space to all political parties and candidates.

4. There is a need for strict compliance with and enforcement of all legislations and regulations pertaining to campaign finance such as sections 228 (c) and (d); 225 and 226 of the 1999 constitution; and sections 92 and 93 of Electoral Act (2010) and section 308 which bars corporations from making donations.

5. There is need to exercise the Electoral Provisions from the 1999 Constitution and make all electoral matters subject to an Act of the National Assembly. This could be replaced with a clause in the Constitution which simply provides that "The National Assembly shall make laws in respect of elections in the country". This would make amendments to the Electoral Act and Composition of electoral body relatively easier than what obtains presently.

6. Rules and regulations concerning the financial activities of political parties are reviewed from time to time and are enforced by both the electoral umpire and anti-corruption agencies to make the parties more active in their responsibilities.

7. Political parties should disclose information about how they raise their finances and acquire assets and the spending. This will help a great deal in the campaign for transparency and accountability.

8. We need to define corruption in an election environment - poverty and illiteracy motivates money changing hands we must therefore tackle these problems to eradicate corruption in elections in Kenya and Nigeria

9. Political parties as an institution are weak lacking in ideologies and membership hence multiple memberships. ECK is has an important role in bringing internal party democracy and ensuring the same during party 
nominations, however it should not load on political parties but instead take the role of a facilitator. INEC in Nigeria perform this function well and should be copied by ECK.

10. The ECK should be proactive in enforcing the Election Offences Act. Nigeria should emulate Kenya by establishing an Election Offences Tribunal as recommended by Uwais Committee. Ethnic mobilization as a mechanism for parties should be given a positive perception too.

\section{Conclusion}

Campaign expenditure by parties and candidates in the electoral process in Kenya remains legally a private affair in the electoral laws that guide the electoral process in Kenya. And we assert here that this is one of the major bottlenecks that lies in the path of the quest to consolidate democracy in Kenya and Nigeria. Obscure and uncontrolled parties and individual candidates undermine the democratization process, good governance, political accountability and citizen faith on the leaders that they elect. A democratization process in any transitional country that does not address the influence of money in politics will certainly come short of consolidating its democracy. Although substantial amounts of money is a basic requirement for political parties in the nomination process the problem lies in how such money is raised and utilized. This is important because political culture that exists in Nigeria and Kenya presently in regard to both the party nomination period and the general elections is one of a time frame that voters need to maximize their exploitation of the candidate and the party or risk waiting another four or five years before such an opportunity arises again. There is thus need to regulate the role of money in the party nomination process as well as the general elections. The point to be noted here is that a bottom up approach is likely to enhance democracy faster in the country than a top down approach. Although regulating internal party affairs might be seen as an assault on democracy through micro-management, there is need to appreciate the fact that if the use of money is regulated only at the general election this will fall short of redressing the injurious impact that money is likely to create at the party nomination stage. For instance if an aspirant gets locked out in a particular party's stronghold as a result of the corrupt influence of money, this cannot be redressed by laws enacted to regulate the general election as that particular aspirant even if he defected must face the corrupt one in a more even field but without the benefit of running on the popular party ticket. In such a case the corrupt politician might win on the strength of his party's ticket and not necessarily on his constituents support for him. Regulation at the party nomination will certainly redress such an anomaly.

In order to decisively address the persistent problems and challenges confronting election administration in Nigeria and Kenya, it is imperative that stakeholders increasingly play positive roles; especially through participation to bring about credible electoral reforms, which provide greater independence of the electoral bodies, stiffer penalties for electoral offenses and guaranteed stable sources of funding. This is why the question in Nigeria and Kenya today is why the escalation in the funding of politics. Several reasons account for this new phenomenon. Some explanations are systematic while some are behavioral which introduces a social desperation that translates into the merchandizing of election and governance. In an effort to avert this monetization of politics, we must create civil awareness of the dangers of the high monetization of politics, we must create civil awareness of the dangers of the high monetization of politics so that all the citizenry become watchers of the system without which we shall return to political wilderness.

\section{References}

Article 19(1999), The Public's Right to Know: Principles on Freedom of Information Legislation, London: Article 19 available at http://www.article19.org/data/files/pdfs/standards/righttoknow.pdf

Article 19 (2012), Kenya: Draft Campaign Financing Bill, (2011), London: Article 19raft

African Commission on Human and Peoples' Rights, African [Banjul] Charter on Human and Peoples' Rights, (1981), adopted 27 June 1981, OAU Doc. CAB/LEG/67/3 rev. 5, 21 I.L.M. 58 (1982), entered into force 21October 1986, available at http://www.achpr.org/english/_info/charter_en.html.

African Commission on Human and Peoples' Rights, Declaration of Principles on Freedom of Expression in Africa, (2002) adopted by Resolution of the Commission at the 32nd Ordinary Session, 2002, available at http://www.achpr.org/english/_doc_target/ documentation.html?../declarations/declaration_freedom_exp_en.html.

Ayoade, J.A.A. (2006) "Money, Politics and Elections in Nigeria", in INEC's Proceedings and Communiqué of the INEC National Forum on Nigeria's 2007 General Elections: The Critical Challenges Ahead. Abuja: Government printers.

Beyme, K.V. (1985) Political Parties in Western Democracies. Gower: Aldershot.

Centre for Multiparty Democracy - Kenya (2011), Response to Campaign Finance Bill (2011), Nariobi: Centre for Multiparty Democracy - Kenya

Elekwa N.N. (2008), The State, and F. Elections and the Future of Nigeria. Nsukka: Great AP Express Publishers 
Eme, O.I. and Okeke,M.I. (2011). "Nigerian Political Parties, Electoral Reforms and Political Finance: Agenda for Reform", The Constitution, Vol. 11, No 2 (June) Pp 87-115

Eme, O.I (2009), "Political Finance and the Future of Nigeria Political Parties: Agenda for Reform", Nigerian Journal of Administrative Science (NJAS), vol. 8 No 1 and 2 July, pp 142-162.

Eme, O.I. and Ede, H. (2007), "E - Registration and Democratic Process in Nigeria: Challenges in Post - 2007 Nigeria" Unpublished Essay

Emelonye, U. (2004) "Political Finance in Nigeria: A Policy Agenda for Reform, in Ndubuisi Obiorah (ed) Political Finance and Democracy in Nigeria: Prospects and Strategies for Reform. Lagos: Center for Law and Social Action.

Ewing, K.D. (1992), Money, Politics and Law, Oxford: oxford Uni.Press.

Federal Republic of Kenya (2012), The Election Campaign Financing Bill, 2012, Nariobi: Government printers.

Federal Republic of Nigeria (1990) Companies and Allied Matters Act. Lagos Government Printers

Federal Republic of Nigeria (1999), The Constitution, Abuja: Government printers.

Federal Republic of Nigeria (2002) Electoral Act: Abuja: Government Printers.

Federal Republic of Nigeria (2004) Electoral Act: Abuja: Government Printers.

Federal Republic of Nigeria (2005) (National Assembly) Political Finance Bill.

Federal Republic of Nigeria (2006) Electoral Act Abuja: Government printers

Gbadamosi, G (2011) "Socialite Who Invested N25 Million in Senatorial Aspirant Dies", Sunday Tribuine, 13 February, p. 7.

Ilo, U. (2004) "Political Finance Regulation in Nigeria: The Legal Framework", in Ndubuisi Obiorah (ed) Political Finance and Democracy in Nigeria: Prospects and Strategies for Reform. Lagos: Center for Law and Social Action.

Maina, W. (2013), "The money factor in race for Kenya's top job" Business Daily , Friday, March 1

Money and Politics: The Case of Party Nominations in Kenya. (nd)

Nnoli, O. (2003) Introduction to Politics. Revised Second Edition. Enugu: SNAAP Press Ltd.

Obiorah, N. (2004) "Preface", in Ndubuisi Obiorah (ed) Political Finance and Democracy in Nigeria: Prospects and Strategies for Reform. Lagos: Center for Law and Social Action.

Oguntola, S. Adelowo, R and Oluwaseun, V. (2011) "High Cost of Political Offices", The Nation on Sunday February, 20 Pp 17, 53, 58,59 .

Onuanyim, J.C (2011). "Candidates List: and \# 3 Million Bribe Caused Row in INEC", Nigerian Compass and F, A S. F. and Monday, February 21, pp.1, 50.

Osuji, (2011), "Politics: the Most Thriving Industry in Nigeria", Sunday Independent, February 20, p 18.

Pinto-Duschinsky, M (2002) "Financing Politics: A Global View", Journal of Democracy, Vol. 3, Number 4 October.

Pinto-Duschinsky, M. (2002) Handbook on Funding of Parties and Election Campaigns: Overview, Stockholm; International IDEA.

Pinto-Duschinsky, M. (2004) "Financing Politics: A Global View" in Ndubuisi Obiorah (ed) Political Finance and Democracy in Nigeria: Prospects and Strategies for Reform. Lagos: Center for Law and Social Action.

Ujo, A.A. (2000) Understanding Elections: A Guide for Students and Election Managers, Kaduna: Joyce Printers

Walecki, M. (2002) Campaign Finance in Central and Eastern Europe. Washington, D.C: International Foundation for Election System. 